\title{
Myelodysplastic Syndromes: Aspects of Current Medical Care and Economic Considerations in Germany
}

\author{
Norbert Gattermann ${ }^{a} \quad$ Wolf-Karsten Hofmann ${ }^{b} \quad$ Axel Meeßen $^{c}$ Stephan Schmitz ${ }^{d}$ \\ Anton Tsamaloukas ${ }^{\mathrm{e}}$ Tanja Vollmer ${ }^{\mathrm{f}} \quad$ Ulrich Wedding ${ }^{g} \quad$ Carlotta Plesnila-Frank ${ }^{\mathrm{h}}$ \\ Wolfgang Schramm ${ }^{i}$ Karin Berger ${ }^{i}$ \\ aUniversitätsklinikum Düsseldorf; ' ${ }^{b}$ Charité Campus Benjamin Franklin, Berlin; \\ 'Verband der Angestellten-Krankenkassen e.V./Arbeiter-Ersatzkassen-Verband e.V., Siegburg; dHämatologe/Onkologe, Cologne; \\ eInternist/Onkologe, Hilden; fPsycho-Onkologin, Rotterdam; 9Universitätsklinikum Jena; \\ hMERG-Forschungsgruppe Medizinische Ökonomie, Munich; 'Klinikum der Universität München, Munich, Germany
}

\section{Key Words}

Myelodysplastic syndromes · Erythrocyte transfusion . Geriatrics · Burden of illness - Quality of life

\section{Summary}

Myelodysplastic syndromes (MDS) are a heterogeneous group of diseases mainly affecting older people. The use of an increasing number of therapeutic options depends on a systematic risk stratification of the patients. A high percentage of MDS patients need blood transfusions as supportive care, which influence quality of life and cause a great part of the costs generated by MDS therapy. In this article which is based on a workshop about the burden of MDS held in October 2006 in Munich, MDS is discussed with regard to different aspects: current therapies, transfusion medicine, geriatrics, quality of life, and health economic aspects.

\section{Introduction}

Myelodysplastic syndromes (MDS) encompass different hematological conditions characterized by chronic cytopenia (anemia, thrombocytopenia, neutropenia) and abnormal cellular maturation of hematopoiesis. Patients with MDS are at risk of symptomatic anemia, bleeding complications, and infections [1]. Another life-threatening factor is progression to acute leukemia in approximately $20 \%$ of the patients, which is often refractory to treatment compared to de novo acute myeloid leukemia (AML) [2, 3]. MDS are clonal disorders of the pluripotent hematopoietic stem cells resulting in different

\section{Schlüsselwörter}

Myelodysplastische Syndrome - Erythrozytentransfusion - Geriatrie · Krankheitskosten · Lebensqualität

\section{Zusammenfassung}

Myelodysplastische Syndrome (MDS) sind eine heterogene Gruppe von Erkrankungen, die hauptsächlich ältere Menschen betreffen. Welche der inzwischen verfügbaren therapeutischen Optionen eingesetzt werden sollte, hängt von einer systematischen Risikostratifizierung der Patienten ab. Ein hoher Prozentsatz von MDS-Patienten benötigt Bluttransfusionen als unterstützende Therapie, welche die Lebensqualität beeinflussen und einen großen Teil der Kosten der MDS-Therapie verursachen. Dieser Beitrag basiert auf einem Workshop mit dem Titel "MDS - Burden of Disease» (Oktober 2006 in München), und befasst sich mit der Erkrankung unter therapeutischen, versorgungsrelevanten und gesundheitsökonomischen Gesichtspunkten.

forms of cytopenia of peripheral blood cells. The bone marrow is at the same time hypercellular, normocellular, or, in rare cases, hypocellular, and often shows morphological changes in all cell lines. The contrast between peripheral blood cytopenia on the one hand, and normal or increased bone marrow cellularity on the other hand, is attributable to ineffective hematopoiesis, with a large proportion of precursor cells dying prematurely in the bone marrow. This mainly occurs through apoptosis. However, it is still unclear which intrinsic or external factors trigger the high rate of apoptosis. In more than $90 \%$ of cases, the etiology of the disease is unknown. Secondary MDS is linked to prior treatments with intensive chemo- or radio-

\begin{tabular}{ll}
\hline KARGER & $\oplus$ 2008 S. Karger GmbH, Freiburg \\
Fax +49 7614520714 & Accessible online at: \\
$\begin{array}{l}\text { E-mail Information@Karger.de } \\
\text { www.karger.com }\end{array}$ & www.karger.com/onk
\end{tabular}


Table 1. WHO classification of myelodysplastic syndromes (MDS) (based on [58])

\begin{tabular}{|c|c|c|}
\hline Subtype & Blood & Bone marrow \\
\hline Refractory anemia (RA) & anemia; no or rare blasts & $\begin{array}{l}\text { erythroid dysplasia only, }<5 \% \text { blasts; }<15 \% \\
\text { ringed sideroblasts }\end{array}$ \\
\hline $\begin{array}{l}\text { Refractory cytopenia with multilineage } \\
\text { dysplasia (RCMD) }\end{array}$ & $\begin{array}{l}\text { cytopenias (bicytopenia or pancytopenia); } \\
\text { no or rare blasts; no Auer rods; }<1 \times 10^{9} / 1 \\
\text { monocytes }\end{array}$ & $\begin{array}{l}\text { dysplasia in } \geq 10 \% \text { of cells in } \geq 2 \text { myeloid cell } \\
\text { lines; }<5 \% \text { blasts; no Auer rods; }<15 \% \text { ringed } \\
\text { sideroblasts }\end{array}$ \\
\hline $\begin{array}{l}\text { Refractory anemia with ringed } \\
\text { sideroblasts (RARS) }\end{array}$ & anemia, no blasts & $\begin{array}{l}\text { erythroid dysplasia only, }<5 \% \text { blasts; } \geq 15 \% \\
\text { ringed sideroblasts }\end{array}$ \\
\hline $\begin{array}{l}\text { Refractory cytopenia with multilineage } \\
\text { dysplasia and ringed sideroblasts } \\
\text { (RCMD-RS) }\end{array}$ & $\begin{array}{l}\text { cytopenias (bicytopenia or pancytopenia); } \\
\text { no or rare blasts; no Auer rods; } \\
<1 \times 10^{9} / 1 \text { monocytes }\end{array}$ & $\begin{array}{l}\text { dysplasia in } \geq 10 \% \text { of cells in } \geq 2 \text { myeloid cell } \\
\text { lines; }<5 \% \text { blasts; no Auer rods; } \geq 15 \% \text { ringed } \\
\text { sideroblasts }\end{array}$ \\
\hline $\begin{array}{l}\text { Refractory anemia with excess blasts-1 } \\
\text { (RAEB-1) }\end{array}$ & $\begin{array}{l}\text { cytopenias } ;<5 \% \text { blasts, no Auer rods; } \\
<1 \times 10^{9} / 1 \text { monocytes }\end{array}$ & $\begin{array}{l}\text { unilineage or multilineage dysplasia; } 5 \% \text { to } 9 \% \\
\text { blasts; no Auer rods }\end{array}$ \\
\hline $\begin{array}{l}\text { Refractory anemia with excess blasts- } 2 \\
\text { (RAEB-2) }\end{array}$ & $\begin{array}{l}\text { cytopenias; } 5-19 \% \text { blasts; Auer rods } \pm \text {; } \\
<1 \times 10^{9} / 1 \text { monocytes }\end{array}$ & $\begin{array}{l}\text { unilineage or multilineage dysplasia } 10 \% \text { to } 19 \% \\
\text { blasts; Auer rods } \pm\end{array}$ \\
\hline $\begin{array}{l}\text { Myelodysplastic syndrome, unclassified } \\
\text { (MDS-U) }\end{array}$ & cytopenias; no or rare blasts; no Auer rods & $\begin{array}{l}\text { unilineage dysplasia in granulocytes or } \\
\text { megakaryocytes; }<5 \% \text { blasts; no Auer rods }\end{array}$ \\
\hline MDS associated with isolated del (5q) & $\begin{array}{l}\text { anemia; }<5 \% \text { blasts; platelets normal or } \\
\text { increased }\end{array}$ & $\begin{array}{l}\text { normal to increased megakaryocytes with } \\
\text { hypolobated nuclei; }<5 \% \text { blasts; no Auer rods; } \\
\text { isolated del }(5 \mathrm{q})\end{array}$ \\
\hline
\end{tabular}

therapy. Chromosomal alterations, especially deletions of genes which are crucial for cell growth, differentiation, and signal transduction in hematopoietic stem cells (e.g. on chromosomes $1,5,7,11,13,20)$, play an important role [4].

There are no typical early symptoms of MDS. Patients present with fatigue, petechial bleeding, or frequent infections due to the different forms of cytopenia. However, in elderly patients anemia and MDS are often diagnosed accidentally when patients are treated for a different disease. MDS is diagnosed by morphological and cytochemical analysis of peripheral blood and bone marrow, as well as cytogenetic and molecular biological analysis of the bone marrow aspiration. Bone marrow biopsy with immune histochemistry and immune phenotyping of the aspiration by fluorescence-activated cell sorting (FACS) are additional techniques. Other underlying causes resulting in the clinical picture of MDS such as alcohol and drug abuse, medication, or prior chemo- and or radiotherapy should be sought. Furthermore, vitamin B12, folic acid, and copper deficiency should be excluded [5, 6]. Patients with MDS have been classified into subgroups according to the French-AmericanBritish (FAB) consensus conference in 1982 [7]. The current form of classification is a modification of the FAB consensus by the World Health Organization (WHO) as shown in table 1.

\section{Epidemiology and Risk Stratification}

MDS are a relatively common hematological disorder. It is a disease of elderly patients, and it is rarely found in adolescents or young adults. The average age at diagnosis is between 65 and 70 years. The MDS registry at Düsseldorf has been col- lecting patient data in Germany for a long time. Reviewing this data base, an overall incidence of MDS of 5/100,000 inhabitants per year was revealed. The incidence increases rapidly in the older patient groups, and reaches 20-50 cases per 100,000 inhabitants in the group older than 70 years. These data are comparable to the estimated incidence in the industrialized world. Men develop MDS slightly more often than women and are even predominant in the older patient groups. Although the incidence in different age groups did not change when surveying a longer period of time, the future will bring an increase in the total number of MDS patients. The major contributing factor is the 'graying society', the increasing average age in the populations of the western world. Improved diagnostics (cytogenetics and molecular biological techniques) and a more precise diagnostic approach in anemic old or geriatric patients will possibly reveal formerly undefined MDS patients. Improvement and innovations in MDS therapy and supportive therapy may lead to a prolonged lifetime of these patients, linked with longer disease time and prolonged need for transfusions. Furthermore, there might be an increase in secondary MDS forms due to more aggressive chemotherapies in different malignant diseases.

The FAB classification and the WHO standard helped to systematically classify this heterogeneous disease but were less useful in determining the prognosis [8]. Reviewing the survival data from previous reported studies, variables were considered in a new way to form the 'International Prognostic Scoring System' (IPSS). The percentage of marrow blasts, specific cytogenetic abnormalities, and the number of cytopenias were used in combination to define 4 risk groups for overall survival and progression to AML: low, intermediate-1, intermedi-
478

Onkologie 2008;31:477-484
Gattermann/Hofmann/Meeßen/ Schmitz/Tsamaloukas/Vollmer/Wedding/ Plesnila-Frank/Schramm/Berger 
Table 2a. International Prognostic Scoring System (IPSS): percentage of marrow blasts, specific cytogenetic abnormalities, and number of cytopenias were used in combination to define 4 risk groups for overall survival and progression to $\mathrm{AML}$

\begin{tabular}{|c|c|c|c|c|c|}
\hline \multirow[t]{2}{*}{ Prognostic variable } & \multicolumn{5}{|c|}{ Survival and AML evolution - score value } \\
\hline & 0 & 0.5 & 1.0 & 1.5 & 2.0 \\
\hline $\begin{array}{l}\text { Marrow blasts, } \%^{a} \\
\text { Karyotype } \\
\text { Cytopenia }\end{array}$ & $\begin{array}{l}<5 \\
\text { good } \\
0 / 1\end{array}$ & $\begin{array}{l}5-10 \\
\text { intermediate } \\
2 / 3\end{array}$ & $\begin{array}{l}- \\
\text { poor }\end{array}$ & $11-20$ & $21-30$ \\
\hline
\end{tabular}

aPatients with 20-30\% blasts may be considered as MDS or AML. MDS = Myelodysplastic syndromes; AML = acute myeloid leukemia.

Table 2b. International Prognostic Scoring System (IPSS): resulting risk groups $[13,59]$

\begin{tabular}{lllll}
\hline Risk category & $\begin{array}{l}\text { \% of } \\
\text { IPSS } \\
\text { popula- } \\
\text { tion }\end{array}$ & Score & $\begin{array}{l}\text { Median } \\
\text { survival } \\
\text { in absence } \\
\text { of therapy, } \\
\text { years }\end{array}$ & $\begin{array}{l}\text { 25\% AML } \\
\text { progression } \\
\text { in absence } \\
\text { of therapy, } \\
\text { years }\end{array}$ \\
\hline Low risk & 33 & 0 & 5.7 & 9.4 \\
Intermediate risk-1 & 38 & $0.5-1.0$ & 3.5 & 3.3 \\
Intermediate risk-2 & 22 & $1.5-2.0$ & 1.2 & 1.1 \\
High risk & 7 & $>2.5$ & 0.4 & 0.2 \\
\hline
\end{tabular}

$\mathrm{AML}=$ Acute myeloid leukemia.

Table 3. Düsseldorf score: patient distribution in risk groups and survival $(\mathrm{n}=1,636)$

\begin{tabular}{lll}
\hline Risk & $\begin{array}{l}\text { Patients, } \\
\%\end{array}$ & $\begin{array}{l}\text { Survival, } \\
\text { months }\end{array}$ \\
\hline Low & 15 & 71 \\
Intermediate & 57 & 27 \\
High & 28 & 7 \\
\hline
\end{tabular}

ate-2, and high [9] (table 2a, b). The analysis of patient data from the MDS registry in Düsseldorf showed an average survival time of between 7 and 62 months depending on the risk stratification of the patients. On the basis of the collected data, other prognostic variables such as the lactate dehydrogenase (LDH) serum level were taken into account to develop the Düsseldorf score for the prognostic determination of MDS subgroups [10-12]. The Düsseldorf score (table 3) consists of 3 risk groups: low (0 points), intermediate (1-2), and high (3-4). The following 4 variables get 1 point if present: hemoglobin level $<90 \mathrm{~g} / 1$, platelets $<100 \mathrm{G} / 1$, LDH elevated, blasts in marrow $>5 \%$.

Due to a similar disease course and prognosis, patients with high-risk MDS according to IPSS can be considered as already having AML when it comes to treatment decisions. It is important to note that most patients with MDS, even those with IPSS intermediate risk-2, will die due to bone marrow failure rather than transformation to AML.

\section{Treatment Options in MDS}

Due to the fact that MDS comprises a very heterogeneous group of patients, treatment of MDS should be adjusted individually to every patient. There are 4 major therapeutic goals: control of symptoms caused by cytopenia, improvement of quality of life, improvement of overall survival, and decrease of progression towards AML [9]. The therapeutic approach should be based mainly on 3 features: age, performance status, and the IPSS-defined risk category [13].

Allogeneic hematopoietic stem cell transplantation (SCT) is the only curative chance for patients with MDS. Due to the aggressiveness of the treatment in the past, the age of the patient had to be below 60 years. New non-myeloablative regimens extended the approach into the group of 60-70-year-old patients. However, a lot of preconditions have to be fulfilled: age, performance status, a matched donor, general health status, and a risk group of intermediate-1 or higher. Only an estimated $5 \%$ of MDS patients are eligible for this approach. Despite the curative chance, transplantation- and relapse-related mortality is relatively high and results in a 5-year survival of between 40 and $60 \%$ [14]. If no donor is available, in younger patients at high risk, intensive chemotherapy according to an AML protocol is an alternative to SCT.

Supportive care is the central component for all MDS treatments, and it is the only essential option for the majority of the patients due to advanced age, comorbidities, and the chronic course of MDS. Cytopenia, especially anemia, is one of the major findings in MDS. At least $70 \%$ of patients will become transfusion-dependent during the course of the disease. If thrombocytopenic bleeding occurs, platelet transfusions are needed. Patients should be treated with antibiotics for infection especially when neutropenic. Supportive care also comprises the treatment of other concomitant problems (e.g. heart and lung disease).

Hematopoietic growth factors may be used in MDS, however, a low or decreasing responsiveness is seen in a lot of cases; e.g. recombinant human erythropoietin (EPO) alone leads to a response rate (defined as increasing or stable hemoglobin concentration without the need for transfusion) of only $10-20 \%$ of MDS patients [15]. However, the synergistic combination with granulocyte colony-stimulating factor (G-CSF) leads to elevated response rates in defined patient subgroups, e.g. $70 \%$ in patients with low endogenous EPO levels $(<200 \mathrm{mU} / \mathrm{ml})$, low transfusion need, and an IPSS low or intermediate-1 [16-18]. Further, the Nordic MDS Group sees a potential benefit in combining the two growth factors in the defined subgroups [19]. One reason might be the change in the response criteria (IWG2000 vs. IWG 2006), but further studies are needed.

Immunosuppressive drugs such as antithymocyte globulin (ATG) and cyclosporine can be used in patients with hypocellular bone marrow. In these patients, immune-mediated marrow suppression might play a major role in the etiology of the disease [20-24]. 
Thalidomide has been used as an antiangionetic immunomodulatory drug with inconsistent effects, low response rates, and severe side effects (e.g. fatigue, neuropathy) [25, 26]. Lenalidomide is an orally administered immunomodulatory derivative of this substance without the typical side effects. In a phase II study with transfusion-dependent, erythropoietin-refractory patients, it has shown response rates of $56 \%$ (no transfusions or reduction of more than $50 \%$ ). Most of the patients had an IPSS low or intermediate- 1 . The best results were seen in patients with del(5q), where even cytogenetic responses were achieved [27, 28].

Low and intermediate intensity chemotherapeutic agents are used in patients with intermediate or high IPSS. DNA methyltransferase (DNMT) inhibitors include azacitidine and decitabine. 5-azacitidine has been tested in a phase III trial and showed $7 \%$ complete response (CR), 16\% partial response (PR), and hematological improvement in $36 \%$ of the patients [29]. Decitabine showed an overall response rate of 17\% (including $9 \% \mathrm{CRs}$ ), and additionally $13 \%$ of hematological improvement in patients treated in a phase III trial. There was a trend towards longer median time to progression to AML [30]. Both substances exert their antineoplastic effect by hypomethylation of DNA and direct toxicity on hematopoietic cells. They are supposed to induce re-expression of tumor suppressor genes. The substances are tested in further trials. Cytarabine plays a minor role due to low remission rates.

New drugs have been introduced in trials and MDS therapy, including arsenic trioxide, oral farnesyltransferase inhibitor, inhibitors of tumor necrosis factor alpha, and anti-angiogenesis agents such as anti-VEGF as well as histone deacetylase (HDAC) inhibitors such as valproic acid [31,32].

Several new drugs have been developed for the treatment of MDS, however, not all are yet approved in Europe for this indication. Although clinical trials could show promising results, further studies have to be conducted to show the long-term benefits regarding response rates, overall survival, and quality of life, as well as potential adverse effects and cost effectiveness.

\section{Transfusion Medicine Focusing on MDS}

Patients with MDS are a challenge for transfusion medicine. The previous chapter has shown that cytopenias are the result of ineffective dysplastic hematopoiesis. The majority of these patients need transfusions, especially of red blood cells (RBC). To guarantee an optimal supply for transfusion-dependent patients, a sufficient number of RBC units must be stored at any time in the transfusion center. Calculating an average need of $24 \mathrm{RBC}$ units per MDS patient per year [33], the enormous need in this single patient group connected to relevant costs becomes obvious. While the number of MDS patients will increase in the next years, the supply of blood products will become more difficult, because blood products and donors are getting rare due to the demographic develop- ment. On the other hand, the aging population needs more transfusions, not only in MDS but in other chronic diseases and for surgical procedures. Since blood cannot be synthesized in the laboratory (yet), blood products remain 'special goods', and the indication for every single transfusion should be checked carefully. Consequently, from a general point of view, in transfusion medicine every therapy minimizing the need for transfusion in a certain indication is important to minimize the transfusion-related risks for the patient on one side, and on the other side to save valuable provisions of blood as an (emergency) supply for other patients.

\section{Iron Overload}

The safety of blood products has been increased over the past. In addition, leukoreduction combined with irradiation of the depleted product helped to minimize leukocyte-mediated complications of transfusions such as febrile transfusion reactions, platelet isosensitization, viral infections, and immunosuppression (even though irradiated erythrocyte concentrates are not recommended for MDS patients in general [34]). However, the iron overload in transfusion-dependent patients is one problem of the supportive therapy which cannot be abolished. The iron overload results in secondary hemochromatosis which can cause cardiac, hepatic, and endocrine malfunctions. Patients with an expected prolonged transfusion need, especially those with an IPSS low or intermediate-1, should be considered for iron chelation therapy [35]. In highrisk patients, the benefit will be minimal due to their short survival time. A serum ferritin level of $>1,000 \mu \mathrm{g} / \mathrm{l}$, a high transfusion rate, and the expected duration of transfusion need are important parameters for the decision about treatment with iron chelators. Deferasirox, an easily applicable oral chelation therapy, is now available. It may be difficult to compare survival in patients with or without chelation therapy, since the relationship between iron overload, high ferritin, RBC transfusions, and shorter survival is not completely understood. Generally, it can be stated that long-term RBC transfusion has a negative effect on quality of life and survival in MDS patients [36].

\section{MDS in Germany and Transfusion Dependency}

Based on the data from a literature review, approximately $50 \%$ of MDS patients are transfusion-dependent across all risk groups [37]. In Germany, between 3,800 and 5,400 MDS patients needed transfusions in 2005 . The number will increase due to an estimated increase in the number of MDS patients of approximately $6 \%$ per year. By the year 2010 , the disease will occur in between 10,000 and 14,000 patients. Table 4 correlates the transfusion dependency of MDS patients in Germany with their IPSS score. Due to the lack of published
480

Onkologie 2008;31:477-484
Gattermann/Hofmann/Meeßen/ Schmitz/Tsamaloukas/Vollmer/Wedding/ Plesnila-Frank/Schramm/Berger 
Table 4. MDS patients in Germany according to risk score and transfusion dependency; due to lack of published prevalence data for Germany, a lower [38] (scenario 1) and a higher scenario [39] (scenario 2) of patient numbers were calculated

\begin{tabular}{|c|c|c|c|c|c|c|}
\hline \multirow[t]{2}{*}{ Risk group } & \multicolumn{3}{|c|}{ MDS patients } & \multicolumn{3}{|c|}{ Transfusion-dependent MDS patients } \\
\hline & $\begin{array}{l}\text { Patients, } \\
\% \text { [13] }\end{array}$ & $\begin{array}{l}\text { Scenario 1: } \\
\text { patients, } \mathrm{n}\end{array}$ & $\begin{array}{l}\text { Scenario 2: } \\
\text { patients, } n\end{array}$ & $\begin{array}{l}\text { Patients, } \\
\text { mean n [37] }\end{array}$ & $\begin{array}{l}\text { Scenario 1: } \\
\text { patients, } \mathrm{n}\end{array}$ & $\begin{array}{c}\text { Scenario 2: } \\
\text { patients, } \mathrm{n}\end{array}$ \\
\hline Low & 33 & 2,423 & 3,465 & 39 & 945 & 1,351 \\
\hline Int-1 & 38 & 2,790 & 3,990 & 50 & 1,395 & 1,995 \\
\hline Int-2 & 22 & 1,615 & 2,310 & 63 & 1,018 & 1,455 \\
\hline High & 7 & 514 & 735 & 79 & 406 & 581 \\
\hline Total & 100 & 7,343 & 10,500 & $51^{\mathrm{a}}$ & 3,764 & 5,382 \\
\hline
\end{tabular}

aWeighted average in \% of transfusion-dependent MDS patients considering all risk groups; source: calculations by the Medical Economics Research Group (MERG), Munich, Germany. MDS = Myelodysplastic syndromes; Int $=$ intermediate.

Table 5. Quality of life studies in myelodysplastic syndrome patients

\begin{tabular}{|c|c|c|c|c|c|}
\hline Authors, year [Ref.] & Country & Study type & $\begin{array}{l}\text { Sample } \\
\text { size }\end{array}$ & Data source/methods & Results \\
\hline Caocci et al., 2006 [49] & Italy & cross-sectional & 33 & QLQ-C30 & $\begin{array}{l}\text { QoL can be improved by lowering the amplitude } \\
\text { of hemoglobin fluctuations }\end{array}$ \\
\hline Stasi et al., 2005 [50] & Italy & phase II study & 53 & LASA FACT-AN & $\begin{array}{l}\text { statistically significant correlation between } \\
\text { increased hemoglobin levels and increased QoL } \\
\text { for the responder group }\end{array}$ \\
\hline Oliva et al., 2005 [51] & Italy & cross-sectional & 39 & $\begin{array}{l}\text { Specific questionnaire } \\
\text { QOL-E }\end{array}$ & $\begin{array}{l}\text { QoL in MDS patients is influenced by transfusion } \\
\text { dependency }\end{array}$ \\
\hline $\begin{array}{l}\text { Casadevall et al., } \\
2004[15]\end{array}$ & France & $\begin{array}{l}\text { randomized } \\
\text { clinical trial }\end{array}$ & 60 & FACT-AN & $\begin{array}{l}\text { QoL did not improve significantly under rHuE } \\
\text { PO + RHuG-CSF }\end{array}$ \\
\hline Clavio et al., 2004 [52] & Italy & $\begin{array}{l}\text { prospective, open- } \\
\text { label, unicentric, } \\
\text { non-randomized }\end{array}$ & 11 & FACT-AN & $\begin{array}{l}\text { erythroid response appeared to be clinically } \\
\text { correlated with the improvement of QoL: higher } \\
\text { hemoglobin levels increased QoL }\end{array}$ \\
\hline Spiriti et al., 2004 [53] & Italy & $\begin{array}{l}\text { open-label, } \\
\text { prospective, } \\
\text { multicenter trial }\end{array}$ & 133 & FACT-AN & QoL did improve under treatment with EPO \\
\hline $\begin{array}{l}\text { Hellstrom-Lindberg } \\
\text { et al., } 2003 \text { [17] }\end{array}$ & Sweden & decision model & 63 & QLQ-C30 & QoL did improve significantly under treatment \\
\hline Jansen et al., 2003 [54] & $\begin{array}{l}\text { The Ne- } \\
\text { therlands }\end{array}$ & cross-sectional & 50 & $\begin{array}{l}\text { SF36 MFI Euro QoL- } \\
\text { 5D VAS }\end{array}$ & $\begin{array}{l}\text { the } 3 \text { internationally established methods proved } \\
\text { to be useful in describing HRQoL in MDS patients }\end{array}$ \\
\hline
\end{tabular}

$\mathrm{QoL}=$ Quality of life; $\mathrm{MDS}=$ myelodysplastic syndromes; $\mathrm{EPO}=$ erythropoietin; $\mathrm{rHuEPO}=$ recombinant human erythropoietin;

RHuG-CSF = recombinant human granulocyte colony-stimulating factor; HRQoL = health-related quality of life.

prevalence data for Germany, a lower [38] and a higher scenario [39] of patient numbers were calculated.

\section{MDS and Geriatric Medicine}

The elderly people in a population are a very heterogeneous group sharing the common features of a reduced life expectancy and reduced physiological organ function. The functional abilities are decreasing whereas the number of comorbidities is increasing with higher age. This results in different medications for different diseases, leading to a variety of pharmacodynamic and pharmacokinetic changes. Anemia, the unspecific finding at the beginning of a diagnostic process, is often incidentally diagnosed in routine blood tests. The prevalence of anemia is increasing with age: $8 \%$ of the people older than 65 years and $15-20 \%$ of those in the group older than 85 years are anemic. A variety of studies identified anemia as risk factor for mortality [40-44]. Not only is the prevalence of anemia increased in older age groups, but the risk for developing a malignant disease increases as well [45]. A study from a geriatric department has shown that in $5 \%$ of elderly patients with anemia, MDS is the underlying disease [46]: 'early forms' of MDS such as refractory anemia (RA) and refractory cytopenia with multilineage dysplasia (RMCD) are those predominant in geriatric patients [47]. Generally, anemia is a frequent finding in geriatric patients. A sufficient search for the cause is not always undertaken, so the number of MDS cases is actually probably underdiagnosed. This group of patients is not well studied, and literature describing outcome and quality of life is not available. 
Table 6. Cost studies of transfusion in myelodysplastic syndrome patients

\begin{tabular}{|c|c|c|c|c|c|}
\hline $\begin{array}{l}\text { Authors, country, } \\
\text { year [ref.] }\end{array}$ & Type of study & Scope & $\begin{array}{l}\text { Study } \\
\text { population }\end{array}$ & Perspective & Transfusion costs \\
\hline $\begin{array}{l}\text { Gupta et al., USA, } \\
1999 \text { [57] }\end{array}$ & $\begin{array}{l}\text { retrospective } \\
\text { record analysis }\end{array}$ & $\begin{array}{l}\text { to assess the costs and potential } \\
\text { complications of supportive } \\
\text { (transfusion) care in MDS patients }\end{array}$ & $\begin{array}{l}50 \text { male MDS } \\
\text { patients } \\
\text { diagnosed } \\
\text { between } 1992 \\
\text { and } 1997\end{array}$ & hospital & $\begin{array}{l}\text { transfusion cost/patient/ } \\
\text { year during MDS phase } \\
\text { US } \$ 1,614 \text { (according to } \\
\text { official procurement } \\
\text { prices for American Red } \\
\text { Cross blood products); } \\
\text { US } \$ 4,877 \text { (according to } \\
\text { published average costs at } \\
\text { US teaching hospitals) }\end{array}$ \\
\hline $\begin{array}{l}\text { Casadevall et al., } \\
\text { France, } 2004 \text { [15] }\end{array}$ & clinical trial & $\begin{array}{l}\text { to evaluate health, costs, and } \\
\text { quality of life within } 2 \text { treatment } \\
\text { groups of MDS patients }\end{array}$ & $\begin{array}{l}60 \text { patients } \\
\text { with low-grade } \\
\text { MDS and serum } \\
\text { EPO levels lower } \\
\text { than } 500 \mathrm{IU} / 1\end{array}$ & $\begin{array}{l}\text { French } \\
\text { healthcare } \\
\text { payer and } \\
\text { hospital }\end{array}$ & $\begin{array}{l}\text { treatment with rHuEPO + } \\
\text { rHuG-CSF: } € 6,200 \text { trans- } \\
\text { fusion cost and } € 27,754 \\
\text { total cost per patient; best } \\
\text { supportive care: } € 7,148 \\
\text { transfusion cost and } € 7,846 \\
\text { total cost per patient }\end{array}$ \\
\hline $\begin{array}{l}\text { Goss et al., USA, } \\
2006 \text { [60] }\end{array}$ & $\begin{array}{l}\text { decision } \\
\text { analytic model }\end{array}$ & $\begin{array}{l}\text { cost-effectiveness study with a } \\
\text { 1-year time horizon; comparison } \\
\text { of lenalidomide with BSC without } \\
\text { EPO vs. BSC with EPO }\end{array}$ & $\begin{array}{l}\text { transfusion- } \\
\text { dependent } \\
\text { MDS patients }\end{array}$ & $\begin{array}{l}\text { private payer } \\
\text { in the US }\end{array}$ & $\begin{array}{l}\text { annual cost per patient } \\
\text { under lenalidomide treat- } \\
\text { ment: US } \$ 7,574 \text { transfusion } \\
\text { cost and US } \$ 63,385 \text { total } \\
\text { treatment cost; under } \\
\text { supportive care: US } \$ 18,101 \\
\text { transfusion cost and US\$ } \\
54,940 \text { total treatment cost }\end{array}$ \\
\hline
\end{tabular}

MDS = Myelodysplastic syndromes; EPO = erythropoietin; rHuEPO = recombinant human erythropoietin; RHuG-CSF = recombinant human granulocyte colony-stimulating factor; $\mathrm{BSC}=$ best supportive care.

\section{Focusing on Inpatient and Outpatient Treatment of MDS in Germany}

Patients with either an unclear anemia or a supposed or already diagnosed MDS should be treated by a specialist for hematology and oncology. The therapy often requires cooperation between in- and outpatient departments for hematology/oncology at hospitals and hematologists in office-based practices.

As described earlier, patients often present with unspecific symptoms, or anemia is diagnosed in a routine blood analysis. A profound disease history and clinical examination is followed by a blood analysis. Different causes of anemia must be excluded; a bone marrow aspiration including a cytogenetic examination helps to find the diagnosis. If MDS has been diagnosed, the patient has to be risk stratified with IPSS, age, and performance status, and has to be informed about possible therapeutic strategies. Regarding the chronicity of the disease and the often limited life expectancy in MDS, the primary goal is to facilitate an outpatient treatment and minimize hospital admissions. However, a patient diagnosed with advanced-stage MDS spends $16 \%$ of his remaining life time in a hospital [48]. Red cell transfusions (RCT) and, if necessary, transfusion of platelets can be given in the outpatient departments of hospitals as well as in the office-based setting. The need for RCT is not strictly defined by a certain hemoglobin level, but is relat- ed to the subjective findings of the patient and dependents on comorbidities (e.g. heart disease). Due to strict laws and guidelines concerning the use and quality of blood products in Germany, this best supportive care for MDS patients is connected with high costs.

\section{The Burden of MDS: Quality of Life and Health Economic Aspects}

Existing quality of life studies in MDS patients use generic instruments due to the lack of a specially developed quality of life questionnaire covering MDS (table 5). Two aspects seem to be important for the quality of life of the patients: first, a higher hemoglobin level, which means probably less fatigue and a more active life; second, a decreased need for transfusions, which means fewer visits to the doctors' office and less restrictions in daily life $[15,17,49-54]$. Results of health utility interviews with MDS patients show that patients associate a high hemoglobin value with achieving transfusion independence, generating new health utility values to be used in economic evaluations that compare the health outcomes of therapies in quality-adjusted life years (QALYs) [55]. In elderly compared to younger cancer patients, presence of anemia is independently associated with poor quality of life in addition to poor performance status [56]. However, a more interven- 
tion-specific research on quality of life of MDS patients is demanded to better meet patients' needs in the future [13].

Table 6 summarizes the very few international studies analyzing the costs of MDS, but focusing mainly on the direct costs of anemia and transfusion dependency [15, 57]. An RCT for an individual patient causes costs on every step of the production chain: donation-related direct and indirect costs, expenses for transportation and compatibility tests, costs for material and staff during the transfusion itself, costs for administration and organization of a transfusion medicine department, and expenses for the ongoing improvement and the guarantee of high quality standards. Adding up these costs, the current price of an RBC unit in Germany is 85-150 Euros. Consequently, the cost of RCTs for transfusion-dependent MDS patients in Germany ranges approximately between 7.8 and 20 million Euros per year, or from 1,500 to 5,300 Euros per patient and year. Analyzing these expenses in detail will reveal that MDS patients cause even more costs because of more frequent transfusion-related complications [57]. Additionally, it has to be taken into consideration that there are not only costs for the blood units but also in- or outpatient costs depending on hospitalization or ambulatory treatment for transfusions.

Identifying the real costs of MDS is difficult due to the complexity and heterogeneity of the disease. A first step should be an MDS cost analysis, identifying the resources used and the costs generated by MDS symptoms and therapies: i) anemia (including RCTs, adverse transfusion reactions and complications, iron overload and chelating therapy, the hematopoietic growth factors $\mathrm{rHuEpo}$ and G-CSF); ii) thrombocytopenia (therapy of bleeding complications and platelet transfusions); iii) neutropenia (diagnosis and therapy of infec- tions with antibiotics and antifungal medication); iv) hematopoietic stem cell and bone marrow transplantation; v) intensive and intermediate chemotherapy and its side effects; vi) treatment of unwanted side effects of the primary intervention; vii) influence of MDS and its therapy on comorbidities (e.g. cardiac, pulmonary, vascular disease). All these aspects can only be realized in a complex economic model which does currently not exist for MDS. It could be an important step forward in optimizing the individual therapy of the patient, by treating the disease effectively, reducing the need for supportive care (especially transfusions), and improving quality of life. In a second step, cost effectiveness or cost utility analysis should be conducted, taking quality of life into account. These tools help to identify the advantages (benefit/value) and the disadvantages (costs) of a procedure in a defined period of time monetarily or in relation to quality of life. The results, such as costs per treatment or costs per QALY, can help decision makers, e.g. medical practitioners, hospital managers, or sickness funds, to decide rationally on their limited resources. Asking questions on effectiveness and using evaluation tools do not contradict good quality medical care but must be seen as instruments for fairer resource allocation. Particularly in oncology, innovative pharmacological treatment options which might seem expensive at first glance often offer the only chance to improve survival and quality of life of the patients.

\section{Acknowledgement}

The workshop was financially supported by Celgene GmbH, Munich, Germany.

\section{References}

1 Albitar M, Manshouri T, Shen Y, Liu D, Beran M, Kantarjian HM, Rogers A, Jilani I, Lin CW, Pierce S, Freireich EJ, Estey EH: Myelodysplastic syndrome is not merely 'preleukemia'. Blood 2002;100: 791-798.

2 Germing U, Gattermann N, Strupp C, Aivado M, Aul C: Validation of the WHO proposals for a new classification of primary myelodysplastic syndromes: a retrospective analysis of 1600 patients. Leuk Res 2000;24:983-992.

3 Alessandrino EP, Amadori S, Barosi G, Cazzola M, Grossi A, Liberato LN, Locatelli F, Marchetti M, Morra E, Rebulla P, Visani G, Tura S: Evidenceand consensus-based practice guidelines for the therapy of primary myelodysplastic syndromes. A statement from the Italian Society of Hematology. Haematologica 2002;87:1286-1306.

4 Corey SJ, Minden MD, Barber DL, Kantarjian H, Wang JC, Schimmer AD: Myelodysplastic syndromes: the complexity of stem-cell diseases. Nat Rev Cancer 2007;7:118-129.

5 Bowen D, Culligan D, Jowitt S, Kelsey S, Mufti G, Oscier D, Parker J: Guidelines for the diagnosis and therapy of adult myelodysplastic syndromes. Br J Haematol 2003;120:187-200.

6 Fong T, Vij R, Vijayan A, Dipersio J, Blinder M: Copper deficiency: an important consideration in the differential diagnosis of myelodysplastic syndrome. Haematologica 2007;92:1429-1430.
7 Bennett JM, Catovsky D, Daniel MT, Flandrin G, Galton DA, Gralnick HR, Sultan C: Proposals for the classification of the myelodysplastic syndromes. Br J Haematol 1982;51:189-199.

8 Greenberg PL, Sanz GF, Sanz MA: Prognostic scoring systems for risk assessment in myelodysplastic syndromes. Forum (Genova ) 1999;9:17-31.

9 Greenberg PL, Cox C, LeBeau MM, Fenaux P, Morel P, Sanz G, Sanz M, Vallespi T, Hamblin T, Oscier D, Ohyashiki K, Toyama K, Aul C, Mufti G, Bennett J: International scoring system for evaluating prognosis in myelodysplastic syndromes. Blood 1997;89:2079-2088

10 Aul C, Gattermann N, Heyll A, Germing U, Derigs G, Schneider W: Primary myelodysplastic syndromes: analysis of prognostic factors in 235 patients and proposals for an improved scoring system. Leukemia 1992;6:52-59.

11 Aul C, Gattermann N, Germing U, Runde V, Heyll A, Schneider W: Risk assessment in primary myelodysplastic syndromes: validation of the Düsseldorf score. Leukemia 1994;8:1906-1913.

12 Germing U, Hildebrandt B, Pfeilstocker M, Nosslinger T, Valent P, Fonatsch C, Lubbert M, Haase D, Steidl C, Krieger O, Stauder R, Giagounidis AA, Strupp C, Kundgen A, Mueller T, Haas R, Gattermann N, Aul C: Refinement of the international prognostic scoring system (IPSS) by including $\mathrm{LDH}$ as an additional prognostic variable to improve risk assessment in patients with primary myelodysplastic syndromes (MDS). Leukemia 2005;19:2223-2231.

13 NCCN: Myelodysplastic syndromes version 1,2008. NCCN Clinical Practice Guidelines in Oncology, 2007.

14 Scott BL, Deeg HJ: Hemopoietic cell transplantation for the myelodysplastic syndromes. Arch Immunol Ther Exp (Warsz) 2005;53:297-307.

15 Casadevall N, Durieux P, Dubois S, Hemery F, Lepage E, Quarre MC, Damaj G, Giraudier S, Guerci A, Laurent G, Dombret H, Chomienne C, Ribrag V, Stamatoullas A, Marie JP, Vekhoff A, Maloise F, Navarro R, Dreyfus F, Fenaux P: Health, economic, and quality-of-life effects of erythropoietin and granulocyte colony-stimulating factor for the treatment of myelodysplastic syndromes: a randomized, controlled trial. Blood 2004;104:321-327.

16 Clavio M, Balleari E, Garrone A, Ballerini F, Varaldo R, Michelis GL, Balocco M, Abdall N, Colombo N, Grasso R, Gobbi M: Haemopoietic growth factors in myelodysplastic syndromes: towards patientoriented therapy? J Exp Clin Cancer Res 2005;24: 5-16.

17 Hellstrom-Lindberg E, Gulbrandsen N, Lindberg G, Ahlgren T, Dahl IM, Dybedal I, Grimfors G, Hesse-Sundin E, Hjorth M, Kanter-Lewensohn L, Linder O, Luthman M, Lofvenberg E, Oberg G, Porwit-MacDonald A, Radlund A, Samuelsson J, 
Tangen JM, Winquist I, Wisloff F: A validated decision model for treating the anaemia of myelodysplastic syndromes with erythropoietin + granulocyte colony-stimulating factor: significant effects on quality of life. Br J Haematol 2003;120:1037-1046.

18 Park S, Grabar S, Kelaidi C, Beyne-Rauzy O, Picard F, Bardet V, Coiteux V, Leroux G, Lepelley P, Daniel MT, Cheze S, Mahe B, Ferrant A, Ravoet C, Escoffre-Barbe M, Ades L, Vey N, Aljassem L, Stamatoullas A, Mannone L, Dombret H, Bourgeois K, Greenberg P, Fenaux P, Dreyfus F; GFM group (Groupe Francophone des Myélodysplasies): Predictive factors of response and survival in myelodysplastic syndrome treated with erythropoietin and G-CSF: the GFM experience. Blood 2008;111: 574-582.

19 Jadersten M, Montgomery SM, Dybedal I, PorwitMacDonald A, Hellstrom-Lindberg E: Long-term outcome of treatment of anemia in MDS with erythropoietin and G-CSF. Blood 2005;106:803-811.

20 Sloand EM, Rezvani K: The role of the immune system in myelodysplasia: implications for therapy. Semin Hematol 2008;45:39-48.

21 Sloand EM, Wu CO, Greenberg P, Young N, Barrett $\mathrm{J}$ : Factors affecting response and survival in patients with myelodysplasia treated with immunosuppressive therapy. J Clin Oncol 2008;26:2505-2511.

22 Steensma DP, Dispenzieri A, Moore SB, Schroeder G, Tefferi A: Antithymocyte globulin has limited efficacy and substantial toxicity in unselected anemic patients with myelodysplastic syndrome. Blood 2003;101:2156-2158.

23 Molldrem JJ, Leifer E, Bahceci E, Saunthararajah Y, Rivera M, Dunbar C, Liu J, Nakamura R, Young NS, Barrett AJ: Antithymocyte globulin for treatment of the bone marrow failure associated with myelodysplastic syndromes. Ann Intern Med 2002. 137:156-163.

24 Killick SB, Mufti G, Cavenagh JD, Mijovic A, Peacock JL, Gordon-Smith EC, Bowen DT, Marsh JC: A pilot study of antithymocyte globulin (ATG) in the treatment of patients with 'low-risk' myelodysplasia. Br J Haematol 2003;120:679-684.

25 Moreno-Aspitia A, Colon-Otero G, Hoering A, Tefferi A, Niedringhaus RD, Vukov A, Li CY, Menke DM, Geyer SM, Alberts SR: Thalidomide therapy in adult patients with myelodysplastic syndrome. A North Central Cancer Treatment Group phase II trial. Cancer 2006;107:767-772.

26 Bouscary D, Legros L, Tulliez M, Dubois S, Mahe B, Beyne-Rauzy O, Quarre MC, Vassilief D, Varet B, Aouba A, Gardembas M, Giraudier S, Guerci A, Rousselot P, Gaillard F, Moreau A, Rousselet MC, Ifrah N, Fenaux P, Dreyfus F: A non-randomised dose-escalating phase II study of thalidomide for the treatment of patients with low-risk myelodysplastic syndromes: the Thal-SMD-2000 trial of the Groupe Francais des Myelodysplasies. Br J Haematol 2005;131:609-618.

27 List A, Kurtin S, Roe DJ, Buresh A, Mahadevan D, Fuchs D, Rimsza L, Heaton R, Knight R, Zeldis JB: Efficacy of lenalidomide in myelodysplastic syndromes. N Engl J Med 2005;352:549-557.

28 List A, Dewald G, Bennett J, Giagounidis A, Raza A, Feldman E, Powell B, Greenberg P, Thomas D, Stone R, Reeder C, Wride K, Patin J, Schmidt M, Zeldis J, Knight R: Lenalidomide in the myelodysplastic syndrome with chromosome $5 \mathrm{q}$ deletion. N Engl J Med 2006;355:1456-1465.

29 Silverman LR, Demakos EP, Peterson BL, Kornblith AB, Holland JC, Odchimar-Reissig R, Stone RM, Nelson D, Powell BL, DeCastro CM, Ellerton J, Larson RA, Schiffer CA, Holland JF: Randomized controlled trial of azacitidine in patients with the myelodysplastic syndrome: a study of the cancer and leukemia group B. J Clin Oncol 2002;20: 2429-2440.
30 Kantarjian H, Issa JP, Rosenfeld CS, Bennett JM, Albitar M, Dipersio J, Klimek V, Slack J, de CC, Ravandi F, Helmer R, III, Shen L, Nimer SD, Leavitt R, Raza A, Saba H: Decitabine improves patient outcomes in myelodysplastic syndromes: results of a phase III randomized study. Cancer 2006;106: 1794-1803.

31 Grudeva-Popova J: New options in the treatment of myelodysplastic syndrome. J BUON 2005;10: 35-42.

32 Steensma DP, Tefferi A: Risk-based management of myelodysplastic syndrome. Oncology (Williston Park) 2007;21:43-54.

33 Gattermann N: Klinische Folgen der Eisenüberladung bei myelodysplastischen Syndromen und Möglichkeiten der Behandlung mit Chelatbildnern; in Hematology/Oncology Clinics, Ergänzungsband $1,2005$.

34 Bundesärztekammer: Leitlinien zur Therapie mit Blutkomponenten und Plasmaderivaten, ed 3, überarbeitete und erweiterte Auflage. Köln, Deutscher Ärzte-Verlag, 2003.

35 Gattermann N: Oral iron chelators in myelodysplastic syndromes. Onkologie 2005;28(suppl 3): abstr 89

36 Balducci L: Transfusion independence in patients with myelodysplastic syndromes: impact on outcomes and quality of life. Cancer 2006;106:20872094.

37 Brechignac S, Hellstrom-Lindberg E, Bowen D, DeWitte T, Cazzola M, Fenaux P: Quality of life and economic impact of red blood cell (RBC) transfusions on patients with myelodysplastic syndromes (MDS). Blood 2004;104 (Part 2):263b (abstr 4716)

38 Myelodysplastic syndromes. An underserved population offers commercial opportunity. ${ }^{\circledR}$ Report by Datamonitor, 2005.

39 Williamson PJ, Kruger AR, Reynolds PJ, Hamblin TJ, Oscier DG: Establishing the incidence of myelodysplastic syndrome. Br J Haematol 1994;87: 743-745.

40 Kikuchi M, Inagaki T, Shinagawa N: Five-year survival of older people with anemia: variation with hemoglobin concentration 1. J Am Geriatr Soc 2001;49:1226-1228.

41 Denny SD, Kuchibhatla MN, Cohen HJ: Impact of anemia on mortality, cognition, and function in community-dwelling elderly. Am J Med 2006;119: 327-334.

42 Penninx BW, Pahor M, Woodman RC, Guralnik JM: Anemia in old age is associated with increased mortality and hospitalization. J Gerontol A Biol Sci Med Sci 2006;61:474-479.

43 Culleton BF, Manns BJ, Zhang J, Tonelli M, Klarenbach S, Hemmelgarn BR: Impact of anemia on hospitalization and mortality in older adults. Blood 2006;107:3841-3846.

44 Patel KV, Harris TB, Faulhaber M, Angleman SB, Connelly S, Bauer DC, Kuller LH, Newman AB, Guralnik JM: Racial variation in the relationship of anemia with mortality and mobility disability among older adults. Blood 2007;109:4663-4670.

45 Edwards BK, Howe HL, Ries LA, Thun MJ, Rosenberg HM, Yancik R, Wingo PA, Jemal A, Feigal EG: Annual report to the nation on the status of cancer, 1973-1999, featuring implications of age and aging on U.S. cancer burden 7. Cancer 2002;94: 2766-2792.

46 Joosten E, Pelemans W, Hiele M, Noyen J, Verhaeghe R, Boogaerts MA: Prevalence and causes of anaemia in a geriatric hospitalized population 18 . Gerontology 1992;38:111-117.

47 Dewulf G, Gouin I, Pautas E, Gaussem P, Chaibi P, Andreux JP, Siguret V: [Myelodisplastic syndromes diagnosed in a geriatric hospital: morphological profile in 100 patients]. Ann Biol Clin (Paris) 2004; 62:197-202.
48 Pitako JA, Haas PS, van den BJ, Muller-Berndorff H, Kundgen A, Germing U, Wijermans PW, Lubbert M: Quantification of outpatient management and hospitalization of patients with high-risk myelodysplastic syndrome treated with low-dose decitabine 1. Ann Hematol 2005;84(suppl 13) 25-31.

49 Caocci G, Baccoli R, Ledda A, Littera R, La Nasa G: A mathematical model for the evaluation of amplitude of hemoglobin fluctuations in elderly anemic patients affected by myelodysplastic syndromes: correlation with quality of life and fatigue. Leuk Res 2007:31:249-252.

50 Stasi R, Abruzzese E, Lanzetta G, Terzoli E, Amadori S: Darbepoetin alfa for the treatment of anemic patients with low- and intermediate-1-risk myelodysplastic syndromes. Ann Oncol 2005;16: 1921-1927.

51 Oliva EN, Dimitrov BD, Benedetto F, D'Angelo A Nobile F: Hemoglobin level threshold for cardiac remodeling and quality of life in myelodysplastic syndrome. Leuk Res 2005;29:1217-1219.

52 Clavio M, Nobili F, Balleari E, Girtler N, Ballerini F, Vitali P, Rosati P, Venturino C, Varaldo R, Gobbi M, Ghio R, Rodriguez G: Quality of life and brain function following high-dose recombinant human erythropoietin in low-risk myelodysplastic syndromes: a preliminary report. Eur J Haematol 2004;72: 113-120.

53 Spiriti MA, Latagliata R, Niscola P, Cortelezzi A Francesconi M, Ferrari D, Volpe E, Clavio M Grossi A, Reyes MT, Musto P, Mitra ME, Azzara A, Pagnini D, D'Arena G, Spadano A, Balleari E, Pecorari P, Capochiani E, De BE, Perego D Monarca B, Pisani F, Scaramella G, Petti MC: Impact of a new dosing regimen of epoetin alfa on quality of life and anemia in patients with low-risk myelodysplastic syndrome. Ann Hematol 2005;84: 167-176.

54 Jansen AJ, Essink-Bot ML, Beckers EA, Hop WC, Schipperus MR, Van Rhenen DJ: Quality of life measurement in patients with transfusion-dependent myelodysplastic syndromes. Br J Haematol 2003;121:270-274.

55 Goss TF, Szende A, Schaefer C, Knight R, Heptinstall K, Lüppert M, Deschler B, Fenaux P, Mufti G, Killisch S, List A: Value of transfusion-free living in MDS: results of health utility interviews with patients. Clin Adv Hematol Oncol 2007;5 (suppl 10): $6-7$.

56 Wedding U, Rohrig B, Pientka L, Hoffken K: Anaemia-related impairment in quality of life in elderly cancer patients prior to chemotherapy. J Cancer Res Clin Oncol 2007;133:279-286.

57 Gupta P, LeRoy SC, Luikart SD, Bateman A, Morrison VA: Long-term blood product transfusion support for patients with myelodysplastic syndromes (MDS): cost analysis and complications. Leuk Res 1999;23:953-959.

58 Vardiman JW, Harris NL, Brunning RD: The World Health Organization (WHO) classification of the myeloid neoplasms. Blood 2002;100:2292-2302.

59 Greenberg PL, Baer MR, Bennett JM, Bloomfield $\mathrm{CD}$, De Castro CM, Deeg HJ, Devetten MP, Emanuel PD, Erba HP, Estey E, Foran J, Gore SD, Millenson M, Navarro WH, Nimer SD, O'Donnell MR, Saba HI, Spiers K, Stone RM, Tallman MS: Myelodysplastic syndromes clinical practice guidelines in oncology. J Natl Compr Canc Netw 2006; 4:58-77.

60 Goss TF, Szende A, Schaefer C, Totten PJ, Knight R, Jadersten M, Hellstrom-Lindberg E, List AF: Cost effectiveness of lenalidomide in the treatment of transfusion-dependent myelodysplastic syndromes in the United States. Cancer Control 2006;13 (suppl):17-25. 